\title{
PAI-1 Regulates the Invasive Phenotype in Human Cutaneous Squamous Cell Carcinoma
}

\author{
Jennifer Freytag, ${ }^{1}$ Cynthia E. Wilkins-Port, ${ }^{1}$ Craig E. Higgins, ${ }^{1}$ \\ J. Andrew Carlson, ${ }^{2}$ Agnes Noel, ${ }^{3}$ Jean-Michel Foidart, ${ }^{3}$ Stephen P. Higgins, ${ }^{1}$ \\ Rohan Samarakoon, ${ }^{1}$ and Paul J. Higgins ${ }^{1}$ \\ ${ }^{1}$ Center for Cell Biology \& Cancer Research, Albany Medical College, 47 New Scotland Avenue, Albany, NY 12208, USA \\ ${ }^{2}$ Department of Pathology, Albany Medical College, 47 New Scotland Avenue, Albany, NY 12208, USA \\ ${ }^{3}$ Laboratory of Tumor and Developmental Biology, Groupe Interdisciplinaire de Génoprotéomique Appliqué-Cancer, University of Liège, \\ Avenue de l'Hôpital 3, 4000 Liège, Belgium
}

Correspondence should be addressed to Paul J. Higgins, higginp@mail.amc.edu

Received 26 August 2009; Accepted 24 November 2009

Recommended by Guus A. M. S. Van Dongen

\begin{abstract}
The emergence of highly aggressive subtypes of human cutaneous squamous cell carcinoma (SCC) often reflects increased autocrine/paracrine TGF- $\beta$ synthesis and epidermal growth factor receptor (EGFR) amplification. Cooperative TGF- $\beta /$ EGFR signaling promotes cell migration and induces expression of both proteases and protease inhibitors that regulate stromal remodeling resulting in the acquisition of an invasive phenotype. In one physiologically relevant model of human cutaneous SCC progression, TGF- $\beta 1+$ EGF stimulation increases the production of several matrix metalloproteinases (MMPs), among the most prominent of which is MMP-10 — an MMP known to be elevated in SCC in situ. Activation of stromal plasminogen appears to be critical in triggering downstream MMP activity. Paradoxically, PAI-1, the major physiological inhibitor of plasmin generation, is also upregulated under these conditions and is an early event in progression of incipient epidermal SCC. One testable hypothesis proposes that TGF- $\beta 1+$ EGF-dependent MMP-10 elevation directs focalized matrix remodeling events that promote epithelial cell plasticity and tissue invasion. Increased PAI-1 expression serves to temporally and spatially modulate plasmin-initiated pericellular proteolysis, further facilitating epithelial invasive potential. Defining the complex signaling and transcriptional mechanisms that maintain this delicate balance is critical to developing targeted therapeutics for the treatment of human cutaneous malignancies.
\end{abstract}

Copyright () 2009 Jennifer Freytag et al. This is an open access article distributed under the Creative Commons Attribution License, which permits unrestricted use, distribution, and reproduction in any medium, provided the original work is properly cited.

\section{Epithelial Skin Cancer Initiation}

Nonmelanoma skin cancers (NMSCs) (i.e., basal cell, squamous cell, and Merkel cell carcinomas) are the most common human malignancies $[1,2]$. In North America alone, $>50 \%$ of all neoplasms arise in the skin [3] and the incidence of NMSC in Australia for the year 2002 was more than five times the incidence of all other cancers combined [4]. Relative to other cutaneous tumors, advanced squamous cell carcinoma (SCC) is aggressive, resistant to localized therapy with significant associated mortality and increasing in frequency [5].

The emergence of epithelial skin tumors appears causally linked to ultraviolet (UV) radiation exposure. Specific UV-B "signature" base changes $(\mathrm{C} \rightarrow \mathrm{T}$ or $\mathrm{CC} \rightarrow \mathrm{TT})$, particularly in codons 177 (basal cell carcinoma) and 278 (SCC) in the tumor suppressor p53 gene [6-8], likely occur early in epidermal carcinogenesis. Indeed, UV-associated p53 mutations are prevalent in solar radiation-induced actinic keratosis; $10 \%$ of these lesions progress to SCC and 60\% of all SCC arise within actinic keratoses [9-11]. Transition of a normal keratinocyte to an initiated pre- or early malignant phenotype, in fact, often involves loss- or gainof-function mutations in p53, with characteristic karyotypic changes including gains in chromosomes 7, 9, 18 (early on) and $3 \mathrm{q}, 8 \mathrm{q}, 9 \mathrm{q}$, and $11 \mathrm{q}$ in later stages of tumor progression, ras gene mutation/activation/amplified expression (10-30\% incidence), and inactivation of cell cycle inhibitors 
TABle 1: Transcript levels for select Cancer Pathway genes.

\begin{tabular}{|c|c|c|}
\hline Gene name & Symbol & Quiescent versus TGF- $\beta 1+$ EGF \\
\hline Angiopoietin 1 & ANGPT1 & 3.01 \\
\hline Breast cancer 1 , early onset & BRCA1 & -3.18 \\
\hline Cyclin-dependent kinase 2 & CDK2 & 2.46 \\
\hline Cyclin-dependent kinase inhibitor 1A (p21, Cip1) & CDKN1A & 7.41 \\
\hline Interferon $\alpha 1$ & IFN $\alpha 1$ & 5.66 \\
\hline Interferon $\beta 1$, fibroblast & IFN $\beta 1$ & 6.87 \\
\hline Integrin $\alpha 1$ & ITG $\alpha 1$ & 5.66 \\
\hline Integrin $\alpha 2$ & ITG $\alpha 2$ & 18.25 \\
\hline Integrin $\beta 1$ & ITG $\beta 1$ & 11.71 \\
\hline Integrin $\beta 3$ & ITG $\beta 3$ & 59.30 \\
\hline Integrin $\beta 5$ & ITG $\beta 5$ & 5.82 \\
\hline Matrix metallopeptidase 1 & MMP1 & 59.30 \\
\hline Matrix metallopeptidase 9 & MMP9 & 55.33 \\
\hline Metastasis associated 1 & MTA1 & 2.19 \\
\hline Metastasis associated 1 family, member 2 & MTA2 & 1.82 \\
\hline Metastasis suppressor 1 & MTSS1 & 5.58 \\
\hline Platelet-derived growth factor $\beta$ polypeptide & PDGFB & 9.51 \\
\hline Plasminogen activator, urokinase & PLAU & 2.64 \\
\hline Plasminogen activator, urokinase receptor & PLAUR & 8.00 \\
\hline Serpin peptidase inhibitor, clade E (plasminogen activator inhibitor-1) & SERPINE1 & 168.90 \\
\hline Transforming growth factor $\beta 1$ & TGF $\beta 1$ & 5.54 \\
\hline Transforming growth factor $\beta$ receptor 1 & TGF- $\beta$ R 1 & 3.46 \\
\hline Thrombospondin 1 & THBS1 & 9.25 \\
\hline Tumor necrosis factor receptor superfamily, member $10 \mathrm{~b}$ & TNFRSF10B & 2.16 \\
\hline Tumor necrosis factor receptor superfamily, member 25 & TNFRSF25 & 3.53 \\
\hline Vascular endothelial growth factor A & VEGFA & 23.26 \\
\hline
\end{tabular}

[7, 12-15]. While epidermal cancers associated with mutant ras expression may be cell type-dependent [16], molecular events that accompany the development of lesional subsets in both premalignant cutaneous lesions (actinic keratosis) and SCC $[10,11,17]$ are similar. p53 gain-of-function versus loss-of-function mutations, moreover, may actually influence different stages in cutaneous SCC progression with gain-of-function changes associated with acceleration to SCC in the context of an oncogenic ras gene $[14,18]$. At least one p53-activating gain-of-function mutation ( $\mathrm{p} 53^{\mathrm{R} 172 \mathrm{H}}$ ) results in increased skin tumor formation/progression and metastatic spread [18].

\section{Epithelial Cell Plasticity and Tumor Progression}

The accumulated genetic/epigenetic changes accompanying evolution of aggressive subtypes of cutaneous SCC are intertwined in a complex signaling landscape emanating from both tumor cells and stromal-derived elements (e.g., hepatocyte growth factor (HGF); epidermal growth factor (EGF); platelet-derived growth factor (PDGF); transforming growth factor- $\beta$ (TGF- $\beta$ )) [19-24]. TGF- $\beta 1$ is a particularly robust initiator of epithelial "plasticity" (usually referred to as epithelial-to-mesenchymal transition or EMT), a likely facilitator of tumor invasion and metastasis (see, e.g., [22, 24]). The EMT "phenotome" however depends on physiologic context (i.e., embryogenesis, fibrosis/wound healing, tumor progression), the involved cell type, and the actual initiating stimulus [24].

Elevated expression of transforming growth factor$\beta 1$ (TGF- $\beta 1$ ) in the tumor microenvironment appears causally linked to creation of highly aggressive metastatic variants [19-23]. Acquired resistance to TGF- $\beta 1$-mediated growth suppression, moreover, is frequently accompanied by mutation, allelic loss, or misregulation of elements within the TGF- $\beta 1$ signaling network (e.g., TGF- $\beta$ RI, TGF- $\beta$ RII, SMAD2, SMAD4, the coreceptors endoglin, and betaglycan) (see, e.g., [25]). Such signaling defects, particularly in later stage tumors, are often coupled to constitutive epidermal growth factor receptor (EGFR) activation as a result of receptor amplification and/or autocrine ligand release [2630]. The associated reprogramming of gene expression initiates and perpetuates TGF- $\beta 1$-induced phenotypic plasticity [21, 31-37].

Recent data mining of the actual repertoire of plasticity genes (i.e., the EMT transcriptome) has significantly enhanced our understanding of the biology of human cutaneous tumor progression while also providing a comparative 


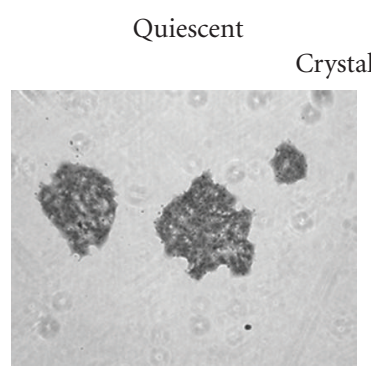

Crystal violet

TGF- $\beta 1+$ EGF

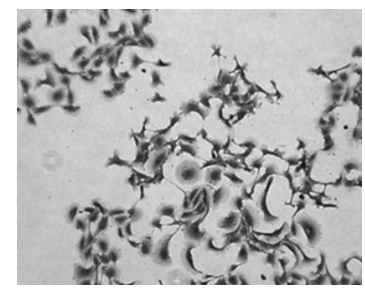

(a)

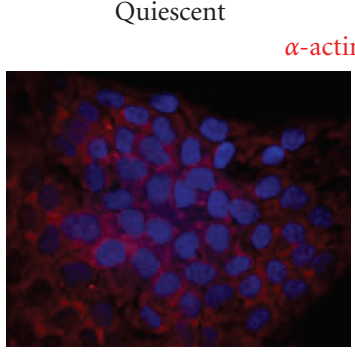

$\alpha$-actin/DAPI

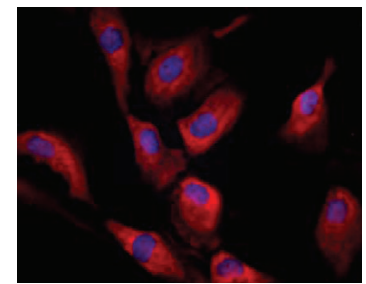

E-cadherin/actin/DAPI
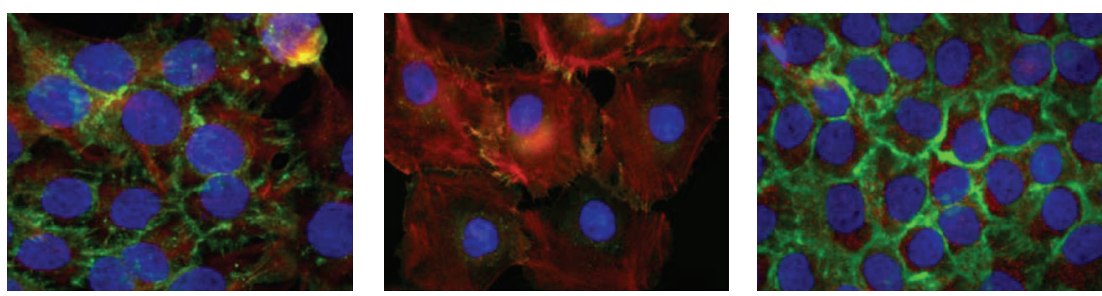

$\alpha 3$ integrin/DAPI

(b)

Vimentin/DAPI

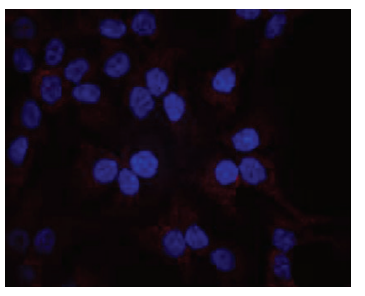

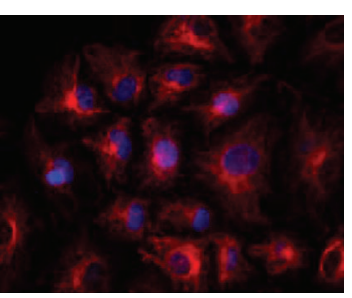

\section{PAI-1/DAPI}
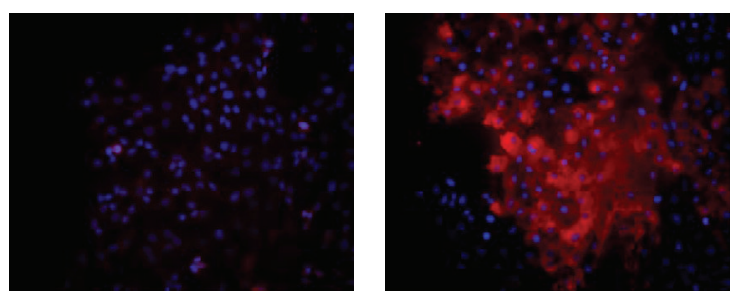

(c)

FIGURE 1: Combination stimulation with TGF- $\beta 1+E G F$ induces a plastic response in HaCaT II-4 cells. A model system was devised in which small colonies of HaCaT II- 4 cells, seeded on tissue culture plastic, were serum-starved followed by addition of TGF- $\beta 1$ ( 1 ng/mL) + EGF $(10 \mathrm{ng} / \mathrm{mL})$. The induced acquisition of a spindle-shaped, highly migratory phenotype, resulted in marked colony dispersal within $24-48$ hours. Cell scattering was accompanied by the loss of E-cadherin (green) and $\alpha 3$ integrin (red) immunostaining at cell-cell junctions, and the gain of several mesenchymal markers, such as $\alpha$-smooth muscle actin and vimentin with construction of a well-developed vimentin filament network. Induced PAI-1 expression (within 6 hours) was a prominent and early feature of growth factor-stimulated EMT.

map of expressed/repressed genes in actinic keratosis and SCC versus normal skin $[38,39]$. Although the spectrum of likely candidate genes identified in different studies varies, plasminogen activator inhibitor type-1 (PAI-1; SERPINE1), the major physiologic regulator of the pericellular plasmingenerating cascade, has consistently emerged as a prominent member of the subset of TGF- $\beta 1$-induced, EMT-associated genes in transformed human keratinocytes [34, 40]. PAI1 is significantly increased in epithelial cells undergoing a mesenchymal-like conversion following activation of the E-cadherin transcriptional repressors, EMT-inducers, Snail, Slug, or E47 indicating that expression of this serine protease inhibitor is a general characteristic of the plastic phenotype [41]. Use of a novel, physiologically-relevant (i.e., p53 mutant, Ha-ras-expressing), dual growth factor (TGF$\beta 1+\mathrm{EGF}$ )-stimulated model of EMT in transformed human keratinocytes (HaCaT II-4 cells) (Figure 1) and microarray profiling defined PAI- 1 as the most highly upregulated transcript of the early gene set (Figure 2; Table 1). The acquisition of a spindle-like, actively motile, behavior in this system was preceded by a decrease in E-cadherin immunoreactivity, the induction of vimentin and $\alpha$-smooth muscle actin (Figure 1), and a genetic signature typical of an aggressive epithelial cell type (Table 1). Ingenuity Pathway analyses of many of these genes (Figure 2; Table 1) indicate that several (e.g., MMPs, uPA, uPAR, SERPINE1) are direct targets of TGF- $\beta 1$, as well as NF- $\kappa \mathrm{B}$, highlighting complex associations among EMT, the tumor microenvironment, and the attendant inflammatory response. Importantly, such clustergrams illustrate the highly coordinate and interdependent nature of the defined pericellular proteolytic cascades involved in focalized stromal degradation and tumor invasion (see, e.g., $[34,35,38-41])$.

Elevated PAI-1 tumor levels signal a poor prognosis and reduced disease-free survival in patients with various malignancies including breast, lung, ovarian, and oral SCC [42-46]. Current data suggest a model in which this SERPIN maintains an angiogenic "scaffold," stabilizes nascent capillary vessel structure, and facilitates tumor cell stromal invasion through precise control of the peritumor proteolytic microenvironment [42, 47, 48]. Indeed, recent targeting of PAI-1 expression in endothelial cells and exogenous 


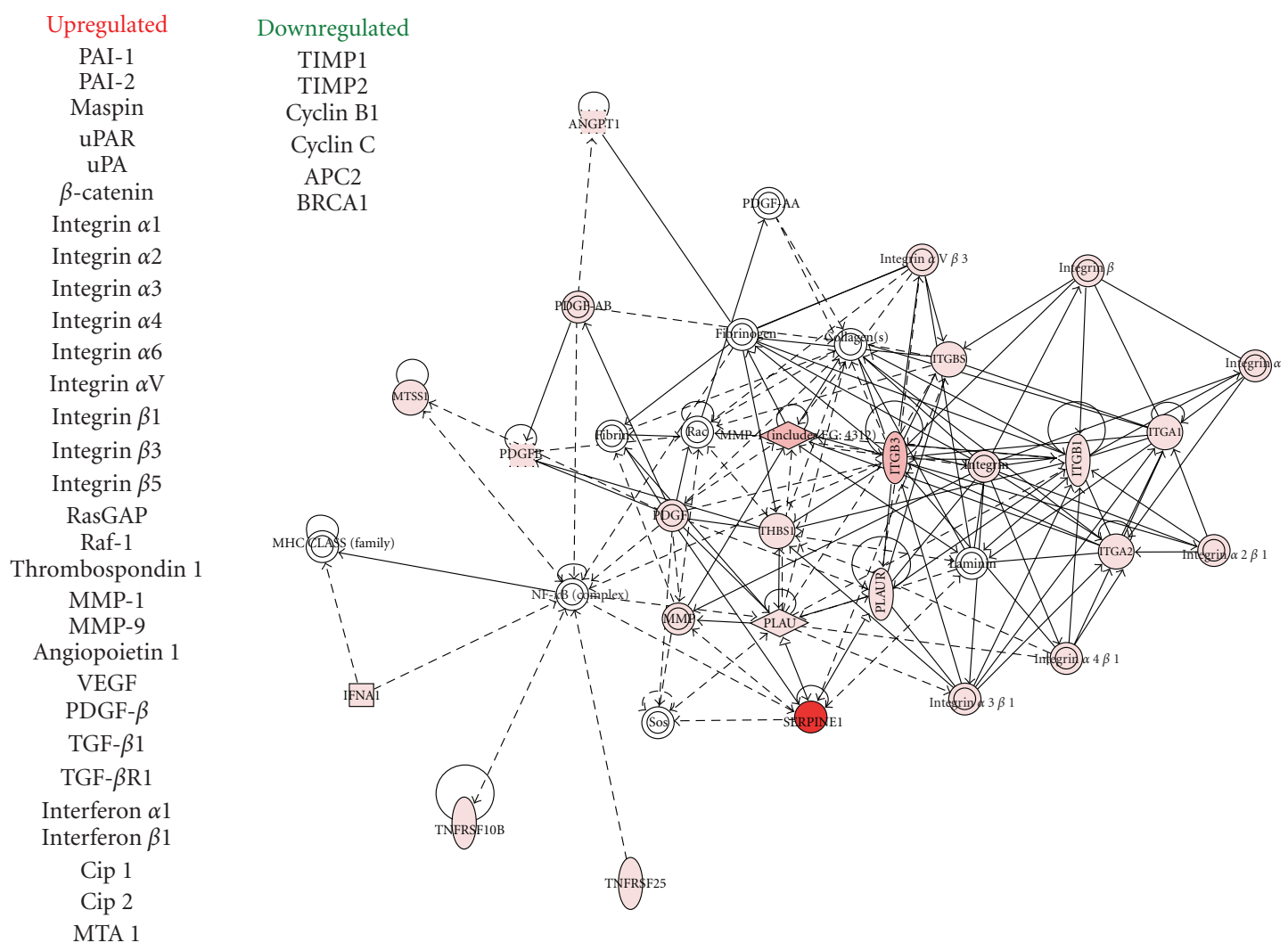

Figure 2: Microarray transcript profiling and pathway analysis of TGF- $\beta 1+E G F-i m p a c t e d ~ g e n e s ~ i n ~ H a C a T ~ I I-4$ keratinocytes. Focused microarrays of dual growth factor-stimulated HaCaT II-4 cells revealed the increased expression of mRNAs encoding proteins involved in angiogenesis, stromal invasion, and control of pericellular proteolysis. PAI-1 transcripts were the most highly upregulated ( $>168$-fold), induced early (within 6 hours) of stimulation and prior to the onset of colony dispersal. Ingenuity Pathway clustergram mapping describes potential functional interactions among the complement of induced genes. Pathway analyses of many of these genes (see also Table 1) indicate that several including uPA, uPAR, SERPINE1, and the MMPs are TGF- $\beta 1$ targets and encode key elements in the integrative proteolytic cascades that regulate focalized stromal degradation and tumor invasion.

introduction of stable PAI-1 variants confirmed that PAI-1 is critical to nascent vessel stabilization and preservation of collagen matrix integrity $[35,49,50]$. In vivo studies, moreover, clearly implicate PAI-1 as an important, perhaps stage-dependent, determinant in cutaneous tumor invasion and the associated angiogenic response $[47,48,51,52]$ (Figure 3). PAI-1 likely "titrates" the extent and locale of collagen matrix remodeling, facilitating tumor invasion into the stroma while maintaining an angiogenic network by inhibiting capillary regression. Molecular knockdown "rescue" strategies, in fact, confirmed PAI-1 to be a positive regulator of keratinocyte migration and an inhibitor of plasminogen-induced anoikis [53]. PAI-1 upregulation is an early event in the progression of incipient epidermal SCC, often localizing to tumor cells and cancer-associated myofibroblasts at the invasive front [54-56] and, more importantly, is a marker with significant prognostic value [43-46]. Identification of PAI-1 (Figure 4(a)) in SCC-proximal $\alpha$-SMA-positive stromal myofibroblasts (Figure 4(b)), furthermore, implies a more global involvement as a matricellular modulator of invasive potential [55-57] consistent with the increasing appreciation of the role of tumor stromal fibroblasts in cancer progression [58].
2.1. Stromal Remodeling Accompanies the Acquisition of Epithelial Plasticity. Costimulation of human cutaneous SCC (HaCaT II-4) cells with TGF- $\beta 1+$ EGF promotes a plastic transition typical of late-stage tumor progression $[35,61]$ (Figure 1). This conversion to a more aggressive phenotype appears to be due, in part, to deregulated growth factor signaling and the transcriptional reprogramming that supports stromal remodeling events [62-69]. Plasmin generation, in particular, accompanies cooperative TGF$\beta 1 /$ EGFR signaling during the evolution of keratinocyte cell plasticity and is a critical event in the downstream activation of a complex and highly interdependent uPA-plasmin-matrix metalloproteinase (MMP) cascade [35, 70-80]. uPA, uPAR, and MMP expression levels are, in fact, significantly upregulated in HaCaT II-4 cells following stimulation with TGF$\beta 1+\mathrm{EGF}$ (e.g., Figure 2). The combination of TGF- $\beta 1+\mathrm{EGF}$, therefore, augments both matrix deposition, through TGF$\beta 1$-dependent upregulation of fibronectin, laminin, proteoglycans, tenascin, thrombospondin and PAI-1 production, and focal degradation by dependent increases in MMPs-1, $-2,-3,-9,-10,-11,-13$, and $-21[35,66-71,81-83]$.

TGF- $\beta 1$ - and/or EGF-stimulated synthesis of the generally epithelial-restricted MMP-10 (stromelysin-2) [72, 73], 


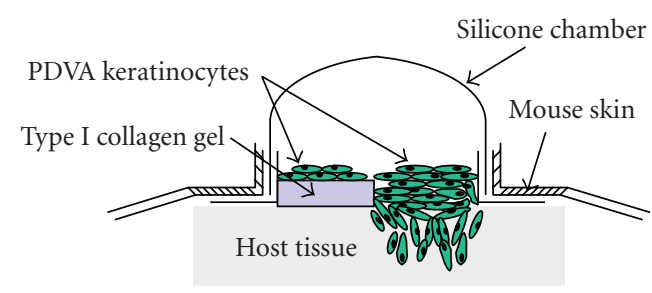

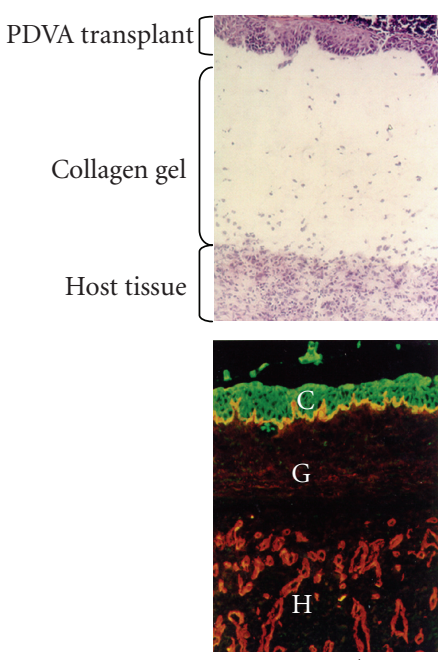

PAI- $1^{-1-}$
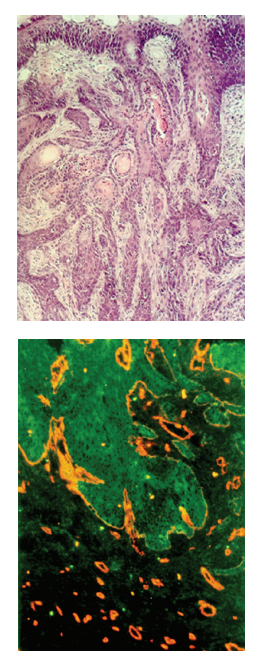

PAI- $1^{+/+}$
FIgURE 3: Cutaneous carcinoma invasion and tumor angiogenesis are suppressed in PAI-1-/- mice. Malignant murine (PDVA) keratinocytes, cultured on a collagen gel in a silicone implantation chamber (top schematic), were transplanted onto PAI- $1^{-/-}$and wild-type PAI- $1^{+/+}$mice. Tumor implantation in PAI- $1^{-/-}$hosts resulted in a dramatic impairment of stromal invasion and failure to develop a supporting angiogenic network unlike the robust responses evident in wild-type animals. Tissue sections were stained with hematoxylin/eosin (two upper panels) or immunostained for keratin (green; to identify transplanted carcinoma cells) and type IV collagen (red; to delineate capillary vessel basement membrane (two lower panels)).

which targets a broad spectrum of matrix components including collagens types III, IV, and V, gelatin, elastin, fibronectin, proteoglycans and laminin, as well as proMMPs$1,-7,-8,-9$, and -13 [74] is particularly significant. SCC of the head and neck, esophagus, oral cavity, and skin expresses elevated levels of MMP-10 [75-78]. While not detectable in intact skin, during cutaneous wound healing MMP-10 is expressed by keratinocytes that comprise the migrating tongue [79], where its activity appears to be important in stromal remodeling during cutaneous wound healing [79]. Despite an inability to cleave collagen type-I, a major dermal component, MMP-10, promotes plasmin-dependent collagenolysis by TGF- $\beta 1+$ EGF-stimulated $\mathrm{HaCaT}$ II- 4 cells in a 3-dimensional system [35]. MMP-10, in fact, "superactivates" collagenase 1 (MMP-1), increasing MMP-1dependent activity $>10$-fold compared to its activation by plasmin alone [72] creating a significant proteolytic axis within the cutaneous environment.

Several MMPs, including MMP-10, are synergistically increased following costimulation of intestinal epithelial cells with TGF- $\beta 1+$ EGF [80]. In HaCaT II-4 keratinocytes, dual stimulation with TGF- $\beta 1+$ EGF induces MMP-10 expression while dramatically enhancing PAI-1 production and stromal invasion [35]. Since type-1 collagen degradation is essential for dermal remodeling, cutaneous tumor invasion may well be considerably dependent on MMP-10 activity. Indeed, MMP-10 upregulation, concomitant with increased STAT3 phosphorylation, accompanies the development of invasive behavior in breast cancer [81]. Similarly, EGF-dependent MMP-10 expression in bladder tumor cells is associated with changes in STAT3 signaling [82]. While the link between STAT3 activation and MMP-10 expression in cutaneous tumor progression remains to be determined, STAT3 overexpression/activation parallels invasive traits in cutaneous SCC $[83,84]$ suggesting that STAT3 may temporally regulate expression of proteolytically active components in the stromal microenvironment. Our studies indicate, moreover, that PAI-1 regulates MMP-10-dependent collagenolysis in TGF- $\beta 1+$ EGF-stimulated HaCaT II-4 keratinocytes [35]. Collectively, the current data suggest a model (Figure 5) in which MMP-10 induction in response to coincubation with TGF- $\beta 1+$ EGF activates MMPs- $1,-7,-8,-9$, and -13 stimulating plasmin-dependent matrix proteolysis. A corresponding upregulation of PAI-1 provides a sensitive focalized mechanism for titering the extent and duration of extracellular matrix degradation consequently sustaining a stromal scaffold necessary for tissue invasion. STAT3 in this context may promote this phenotype by regulating growth factor-dependent expression of critical remodeling factors such as MMP-10 and PAI-1 (Figure 5).

\subsection{TGF- $\beta 1 /$ EGFR Pathway Integration in PAI-1 Expression} Control. In several common carcinoma types, including cutaneous SCC, the combination of TGF- $\beta 1+$ EGF effectively initiates and maintains the dramatic morphological restructuring and genomic responses characteristic of the plastic phenotype $[35,61,80]$. In particular tumor models, the addition of EGF serves to activate the ras $\rightarrow$ raf $\rightarrow$ $\mathrm{MEK} \rightarrow$ ERK cascade as a collateral stimulus to TGF- $\beta$ Rdependent signaling. Clearly, cooperative, albeit complex, interactions between TGF- $\beta 1$ - and EGFR-activated pathways involving EGFR/pp60 ${ }^{\mathrm{c}-\mathrm{src}}, \mathrm{p} 21^{\text {ras }}$ and mitogen-activated extracellular kinase (MEK) [85] and the MAP kinases ERK/p38 appear mechanistically linked to epithelial tumor cell plasticity, at least in HaCaT II-4 cells [28, 30, 8688]. The nonreceptor tyrosine kinase $p p 60^{c-s r c}$ is, in fact, a critical intermediate in a TGF- $\beta 1$-initiated transduction cascade leading to MEK involvement, PAI-1 transcription, and downstream phenotypic responses [28, 85, 86, 88]. TGF$\beta 1$ complements EGF-mediated signaling to the MAPK/AKT pathways to effect EMT consistent with the requirement for oncogenic ras in TGF- $\beta 1$-induced EMT $[89,90]$. Disruption of TGF- $\beta 1$-stimulated ERK1/2 phosphorylation and PAI-1 transcription by src family kinase inhibitors, as well as blockade of EGFR signaling with AG1478, suggests that $\mathrm{pp} 60^{\mathrm{c}-\mathrm{src}}$, perhaps through phosphorylation of the Y845 src-kinase EGFR target residue, regulates MEKERK-dependent PAI-1 expression [28, 85, 91] (Figure 6). 


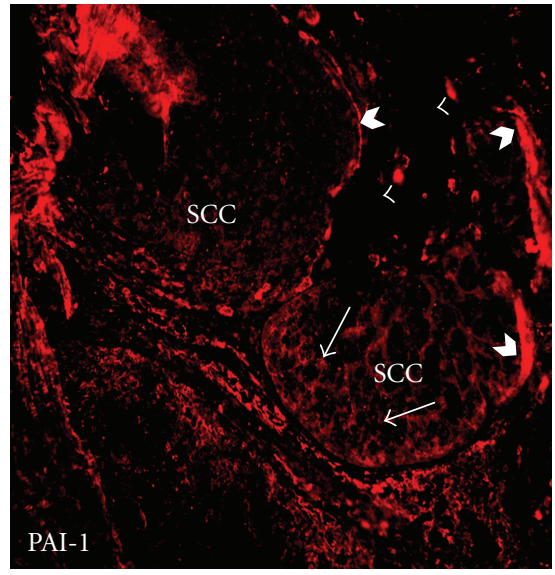

(a)

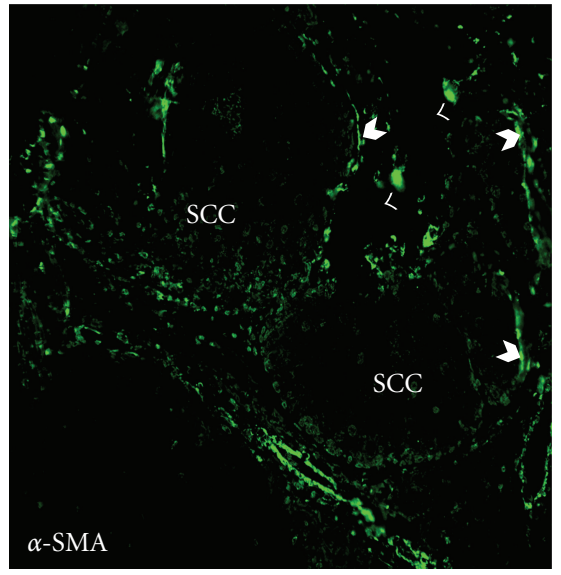

(b)

FIgURE 4: In situ distribution of PAI-1 in an early invasive human cutaneous squamous cell carcinoma. Sections were dually stained for PAI-1 (red; (a)) and $\alpha$-smooth muscle actin ( $\alpha$-SMA, green; (b)). PAI-1 was evident in the SCC epithelium at the invasive front (arrows). Prominent PAI-1-expression also colocalized to $\alpha$-SMA-positive cells, a marker for myofibroblasts, at the carcinoma periphery. Barbed arrowheads indicate PAI- $1 / \alpha$-SMA at the tumor perimeter while arrowheads depict PAI- $1 / \alpha$-SMA in stromal cells.

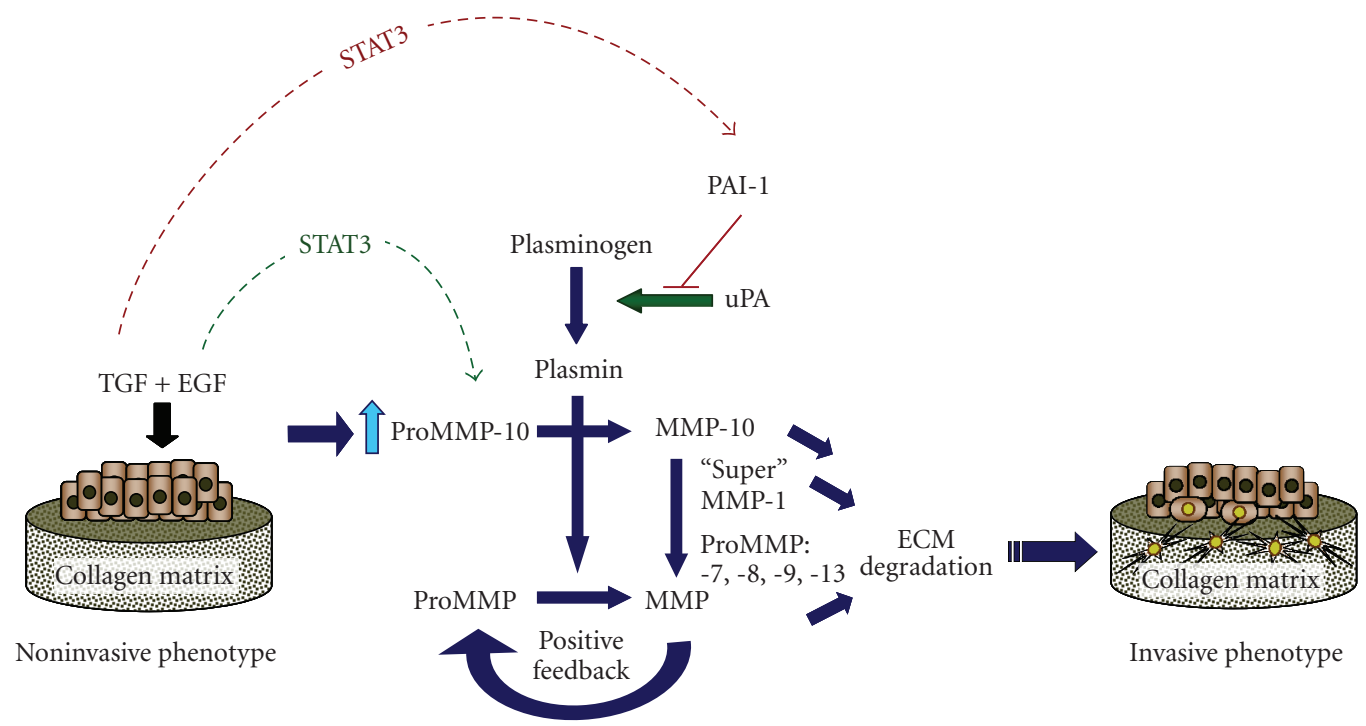

Figure 5: Proposed mechanistic context for TGF- $\beta 1+E G F-e n h a n c e d$ plasmin-dependent collagen matrix remodeling and its contribution to development of an invasive phenotype. Dual growth factor-stimulated HaCaT II-4 keratinocytes cultured on a three-dimensional collagen gel upregulate critical stromal remodeling factors that both disrupt and preserve matrix integrity. In the presence of active plasmin, increased MMP-10 promotes MMP activation and creates a proteolytic axis that accelerates collagen degradation through "superactivation" of MMP1. STAT3 phosphorylation may serve as a temporal switch in this process, through its ability to both promote EGF-stimulated proMMP10 expression and antagonize induction of TGF- $\beta 1$ target genes (i.e., PAI-1, fibronectin) [59]. The synergistic upregulation of PAI-1 in response to TGF- $\beta 1+$ EGF may subsequently shift this proteolytic balance, enabling PAI-1 to "titrate" the extent and locale of collagen matrix remodeling to facilitate tumor cell stromal invasion. Indeed, PAI-1 induction is an early event in this phenotypic transition and required for the motile response since PAI-1 knockdown (with siRNA constructs) effectively inhibited TGF- $\beta 1+$ EGF-initiated colony scattering [60].

While the actual mechanism underlying TGF- $\beta 1$-associated pp60 ${ }^{\text {c-src }}$ kinase/EGFR stimulation remains to be determined, TGF- $\beta 1$-dependent release of EGFR ligands (e.g., HB-EGF, amphiregulin and/or TGF- $\alpha$ ) via MMP- or ADAMdependent processes is one likely possibility for at least some cell types $[60,92]$. Alternatively, the TGF- $\beta 1$-stimulated formation of integrin/FAK/p130 cas/EGFR complexes may initiate ligand-independent EGFR activation and $p p 60^{\mathrm{c}-s r c}$ recruitment $[91,93,94]$. Indeed, in HaCaT cells, TGF- $\beta 1$ transactivates the EGFR in a complex manner requiring $s r c$ kinase signaling and production of reactive oxygen species but may not involve the shedding of EGFR ligands [30, 95]. The effective blockade of TGF- $\beta 1$-stimulated ERK1/2 phosphorylation and PAI-1 transcription by src kinase-targeting 


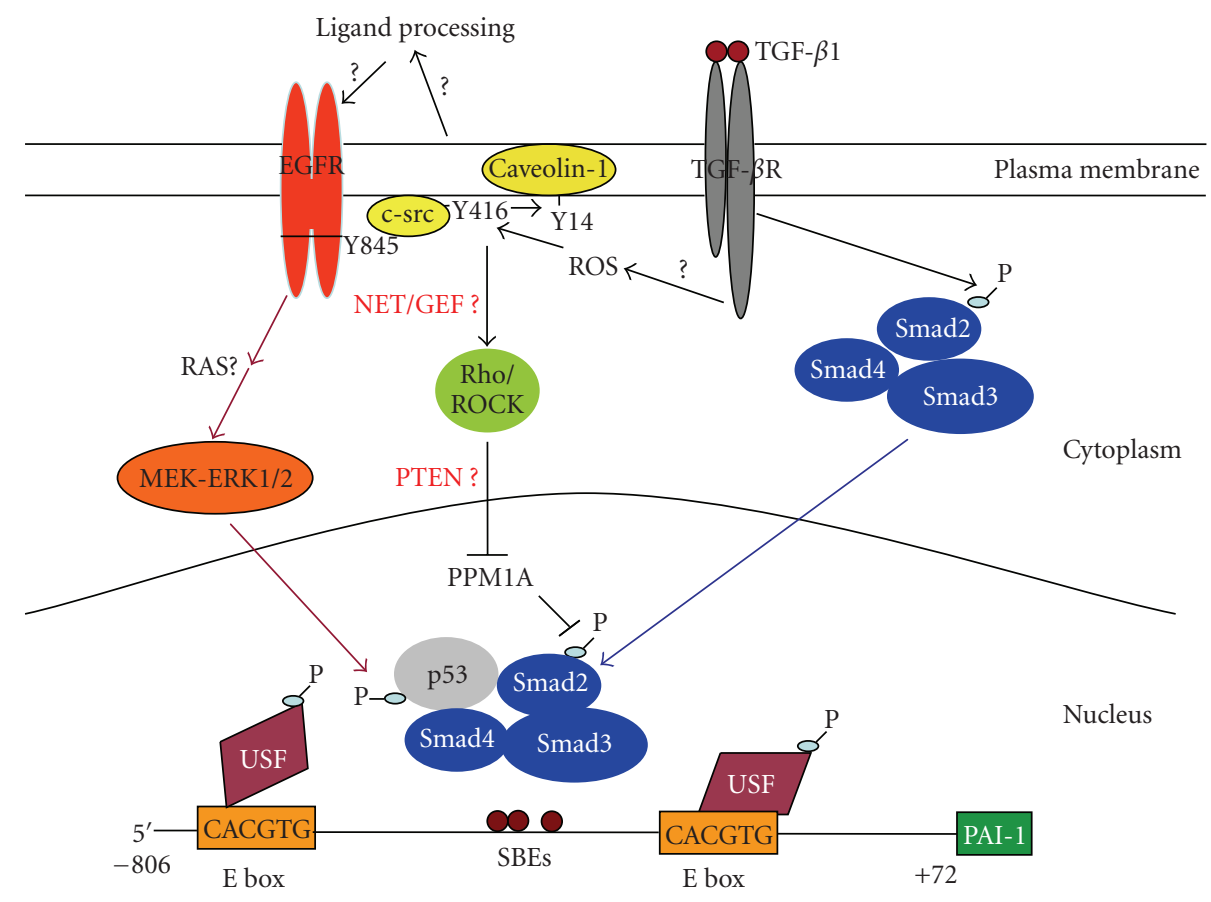

FIGURE 6: A model for TGF- $\beta 1$ induced PAI-1 transcription. Emerging studies suggest that transcriptional outputs from both SMAD2/3 as well as non-SMAD (e.g., EGFR-MEK/ERK) pathways are absolutely critical for TGF- $\beta 1$-mediated PAI-1 induction. Activated $S r c$ kinases (e.g., c-Src), downstream of TGF- $\beta 1$ receptor, function as an upstream regulator of EGFR transactivation (by Y845 phosphorylation). c-Src also modulates Caveolin-1 ${ }^{\mathrm{Y} 14}$ phosphorylation, and likely stimulates Rho/ROCK-dependent maintenance of SMAD2/3 transcriptional activity (by suppressing nuclear levels or activity of the SMAD2/3 phosphatase PPM1A). ERK1/2 (downstream of EGFR activation), or p38 kinases, may phosphorylate p53 and the bHLH-LZ upstream stimulatory factor proteins $1 / 2$ (USF1/2) in response to TGF- $\beta 1$. Indeed, SMAD2/3 appears to cooperate with p53 and USF family transcription factors for maximal TGF- $\beta 1$-directed PAI- 1 gene expression.

pharmacologic agents, as well as the EGFR inhibitor AG1478, and the requirement for MEK-ERK signaling for the full inductive effect of TGF- $\beta 1$, suggests that $\mathrm{pp} 60^{\mathrm{c}-\mathrm{src}}$, perhaps through phosphorylation of the Y845 src-specific EGFR substrate residue regulates the MEK-ERK-dependent PAI-1 expression transduction cascade $[28,30,51,85,86]$. While specific mechanisms remain to be clarified, it is apparent that cooperative EGFR signaling is an essential aspect of TGF- $\beta 1$ stimulated PAI-1 expression which provides novel insights as to the impact of TGF- $\beta 1$ in late-stage human cutaneous tumor progression.

2.3. PAI-1 Transcription: Links to p53. Members of the p53 family are critical elements in a subset of TGF- $\beta 1$ transcriptional responses due, at least in part, to the ability of MAP kinase-phosphorylated p53 to bind SMAD2 [96100]. DNase I footprinting/methylation interference and oligonucleotide mobility shift analyses confirmed, moreover, that p53 binds to a recognition motif in the PAI-1 promoter resulting in both p53 sequence-driven reporter gene transcription and induced expression of the endogenous PAI-1 gene [101]. Two p53 half-sites (AcACATGCCT, cAGCAAGTCC) [Profile Hidden Markov Model score $=82$; 89] likely regulate p53-dependent PAI-1 gene activation [102]. p53-mediated PAI-1 expression control, moreover, is likely to involve nontranscriptional mechanisms as well since p53 binds to a 70 nt sequence on the PAI-1 mRNA 3' UTR resulting in increased mRNA stabilization [103].

p53 is also required for maximal PAI-1 expression in response to TGF- $\beta 1$ since induced transcription is significantly attenuated in p53 siRNA knockdown cells [98] as well as in $\mathrm{p}^{-1-}$ mouse fibroblasts (Samarakoon and Higgins, unpublished data). This is consistent with the observation that p53-deficient lung tumor cells synthesize little or no PAI-1 while vector-engineered introduction of wild-type p53 rescues both basal and inducible PAI-1 expressions [103]. The recent analysis of the upstream region of the PAI-1 gene provides some insight as to the possible mechanisms underlying p53-dependent PAI-1 gene control. The PAI-1 promoter PE2 region hexanucleotide E box (CACGTG), a site juxtaposed to $3 \mathrm{SMAD}$-binding elements, is occupied by upstream stimulatory factor (USF) in response to TGF- $\beta 1$ stimulation $[85,104]$. Phasing analysis revealed that certain bHLH-LZ members of the MYC family (including USF) orient DNA bending toward the minor groove [105] which could potentially promote interactions between p53, bound to its downstream half-site motif, with SMAD2 tethered to the upstream PE2 region SMAD-binding elements, thus, providing a molecular basis for SMAD2/p53 complex formation and subsequent transcriptional activation of the PAI-1 gene (Figure 6). 
2.4. Implications on Cell Growth Control. p53 mutations occur in $40-60 \%$ of all skin cancers $[9,106]$ suggesting that direct p53 transcriptional targets (such as the PAI1 gene) may be activated, repressed, or dysregulated as a consequence of p53 mutation with associated loss or gain of function. Indeed, p53 is a major element in PAI-1 induction in response to TGF- $\beta 1$ [98] and may be critical particularly in the setting of increased autocrine TGF- $\beta 1$ expression during cutaneous SCC progression. The role of PAI-1 in subsequent tumor progression, however, may be more complex than previously appreciated. Ectopic expression of wild-type PAI1 in breast cancer cells or in p53-deficient murine and human fibroblasts, in fact, initiates a senescence-like growth arrest $[92,107]$ while RNAi-mediated PAI-1 knockdown (PAI-1 ${ }^{\mathrm{KD}}$ ) or PAI-1 genetic deficiency (PAI-1 ${ }^{-/-}$genotype) results in escape from replicative senescence in primary mouse and human fibroblasts [107]. Proliferation of PAI-1 $1^{-/-}$endothelial cells, and PAI- $1^{\mathrm{KD}}$ fibroblasts appears due, at least in part, to sustained activation of the PI3K-AKT-GSK3 $\beta$ pathway, increased $\mathrm{AKT}^{\mathrm{Ser} 473}$ phosphorylation, nuclear retention of cyclin D1 [107, 108] and, perhaps, increased inactivation of the tumor suppressor PTEN [108]. Importantly, PAI$1^{-/-}$mouse embryo fibroblasts (MEFs), PAI- ${ }^{\mathrm{KD}} \mathrm{HaCaT}$ keratinocytes, and PAI- $1^{\mathrm{KD}} \mathrm{MEF}$ are resistant to TGF- $\beta 1$ initiated growth inhibition although PAI-1 deficiency does not interfere with canonical TGF- $\beta 1$ signaling such as SMAD phosphorylation or $p 21^{C I P 1}$ and $p 15^{I N K 4 B}$ induction [109].

Collectively, these data suggest a multifunctional relationship between PAI-1 expression and tumor progression. Elevated PAI-1 levels may inhibit (at least transiently) tumor cell proliferation while stimulating migration and stromal invasion by providing a sensitive focalized mechanism for titering the extent and duration of extracellular matrix degradation, sustaining a stromal scaffold necessary for tissue invasion. This carefully orchestrated process may also serve to promote tumor cell survival by preventing anoikis during the precarious process of cell detachment and readhesion to a new, likely foreign, tissue microenvironment. Importantly, these findings underscore the potential diversity of new molecular targets that can be exploited for therapeutic benefit. Refining the current understanding of PAI-1 gene regulation, and relevant signaling pathways, may lead to the discovery of critical regulatory factors that ultimately prove important in stage-specific treatment of human cutaneous malignancies.

\section{Abbreviations}

SCC: $\quad$ Squamous cell carcinoma

EGF: $\quad$ Epidermal growth factor

EGFR: $\quad$ Epidermal growth factor receptor

TGF- $\beta 1$ : $\quad$ Transforming growth factor- $\beta 1$

MMP: $\quad$ Matrix metalloproteinase

NMSC: $\quad$ Nonmelanoma skin cancer

UV: Ultraviolet

TGF- $\beta$ R: $\quad$ TGF- $\beta$ receptor

EMT: $\quad$ Epithelial-to-mesenchymal transition

PAI-1: $\quad$ Plasminogen activator inhibitor type-1

SERPINE1: Serine protease inhibitor, clade E, member 1
uPA: Urokinase plasminogen activator

uPAR: Urokinase plasminogen activator receptor

STAT3: Signal transducer and activators of transcription protein 3

SMAD: Sma/Mad homologues

ERK: Extracellular signal-regulated kinases

MEK: Mitogen-activated protein kinase/ERK kinase

FAK: Focal adhesion kinase

MEFs: Mouse embryo fibroblasts.

\section{Acknowledgment}

This work is supported by NIH Grant GM57242.

\section{References}

[1] M. J. Eide and M. A. Weinstock, "Epidemiology of skin cancer," in Cancer of the Skin, D. S. Rigel, R. J. Friedman, L. M. Dzubow, D. S. Reintgen, J.-C. Bystryn, and R. Marks, Eds., pp. 47-60, Elsevier, Philadelphia, Pa, USA, 2005.

[2] P. G. Lang and J. C. Maize, "Basal cell carcinoma," in Cancer of the Skin, D. S. Rigel, R. J. Friedman, L. M. Dzubow, D. S. Reintgen, J.-C. Bystryn, and R. Marks, Eds., pp. 101-132, Elsevier, Philadelphia, Pa, USA, 2005.

[3] A. Dlugosz, G. Merlino, and S. H. Yuspa, "Progress in cutaneous cancer research," Journal of Investigative Dermatology Symposium Proceedings, vol. 7, no. 1, pp. 17-26, 2002.

[4] M. P. Staples, M. Elwood, R. C. Burton, J. L. Williams, R. Marks, and G. G. Giles, "Non-melanoma skin cancer in Australia: the 2002 national survey and trends since 1985," Medical Journal of Australia, vol. 184, no. 1, pp. 6-10, 2006.

[5] T. H. Nguyen and J. Yoon, "Squamous cell carcinoma," in Cancer of the Skin, D. S. Rigel, R. J. Friedman, L. M. Dzubow, D. S. Reintgen, J.-C. Bystryn, and R. Marks, Eds., pp. 133150, Elsevier, Philadelphia, Pa, USA, 2005.

[6] P. Boukamp, "UV-induced skin cancer: similaritiesvariations," Journal of the German Society of Dermatology, vol. 3, no. 7, pp. 493-503, 2005.

[7] P. Boukamp, W. Peter, U. Pascheberg, et al., "Step-wise progression in human skin carcinogenesis in vitro involves mutational inactivation of $\mathrm{p} 53$, ras $(\mathrm{H})$ oncogene activation and additional chromosome loss," Oncogene, vol. 11, no. 5, pp. 961-969, 1995.

[8] G. Giglia-Mari and A. Sarasin, "TP53 mutations in human skin cancers," Human Mutation, vol. 21, no. 3, pp. 217-228, 2003.

[9] M. Dans and S. S. Fakharzadeh, "Genetic basis of skin cancer," in Cancer of the Skin, D. S. Rigel, R. J. Friedman, L. M. Dzubow, D. S. Reintgen, J.-C. Bystryn, and R. Marks, Eds., pp. 15-27, Elsevier, Philadelphia, Pa, USA, 2005.

[10] B. R. Smoller, "Squamous cell carcinoma: from precursor lesions to high-risk variants," Modern Pathology, vol. 19, supplement 2, pp. S88-S92, 2006.

[11] K. Y. Tsai and H. Tsao, "The genetics of skin cancer," American Journal of Medical Genetics, vol. 131C, no. 1, pp. 82-92, 2004.

[12] P. Boukamp, "Non-melanoma skin cancer: what drives tumor development and progression?" Carcinogenesis, vol. 26, no. 10, pp. 1657-1667, 2005.

[13] S. H. Yuspa, "The pathogenesis of squamous cell cancer: lessons learned from studies of skin carcinogenesis," Journal of Dermatological Science, vol. 17, no. 1, pp. 1-7, 1998. 
[14] S. Frame, R. Crombie, J. Liddell, et al., "Epithelial carcinogenesis in the mouse: correlating the genetics and the biology," Philosophical Transactions of the Royal Society B, vol. 353, no. 1370, pp. 839-845, 1998.

[15] P. K. Tsantoulis, N. G. Kastrinakis, A. D. Tourvas, G. Laskaris, and V. G. Gorgoulis, "Advances in the biology of oral cancer," Oral Oncology, vol. 43, no. 6, pp. 523-534, 2007.

[16] K. Brown, D. Strathdee, S. Bryson, W. Lambie, and A. Balmain, "The malignant capacity of skin tumours induced by expression of a mutant $\mathrm{H}$-ras transgene depends on the cell type targeted," Current Biology, vol. 8, no. 9, pp. 516-524, 1998.

[17] R. J. Akhurst and A. Balmain, "Genetic events and the role of TGF $\beta$ in epithelial tumour progression," Journal of Pathology, vol. 187, no. 1, pp. 82-90, 1999.

[18] C. Caulin, T. Nguyen, G. A. Lang, et al., "An inducible mouse model for skin cancer reveals distinct roles for gain- and lossof-function p53 mutations," Journal of Clinical Investigation, vol. 117, no. 7, pp. 1893-1901, 2007.

[19] W. Cui, D. J. Fowlis, S. Bryson, et al., "TGF $\beta 1$ inhibits the formation of benign skin tumors, but enhances progression to invasive spindle carcinomas in transgenic mice," Cell, vol. 86, no. 4, pp. 531-542, 1996.

[20] G. Portella, S. A. Cumming, J. Liddell, et al., "Transforming growth factor $\beta$ is essential for spindle cell conversion of mouse skin carcinoma in vivo: implications for tumor invasion," Cell Growth and Differentiation, vol. 9, no. 5, pp. 393-404, 1998.

[21] R. Derynck, R. J. Akhurst, and A. Balmain, "TGF- $\beta$ signaling in tumor suppression and cancer progression," Nature Genetics, vol. 29, no. 2, pp. 117-129, 2001.

[22] G. Moreno-Bueno, F. Portillo, and A. Cano, "Transcriptional regulation of cell polarity in EMT and cancer," Oncogene, vol. 27, no. 55, pp. 6958-6969, 2008.

[23] G. Han, S.-L. Lu, A. G. Li, et al., "Distinct mechanisms of TGF- $\beta 1$-mediated epithelial-to-mesenchymal transition and metastasis during skin carcinogenesis," Journal of Clinical Investigation, vol. 115, no. 7, pp. 1714-1723, 2005.

[24] R. Kalluri and R. A. Weinberg, "The basics of epithelialmesenchymal transition," Journal of Clinical Investigation, vol. 119, no. 6, pp. 1420-1428, 2009.

[25] B. Bierie and H. L. Moses, "Tumour microenvironment: TGF $\beta$ : the molecular Jekyll and Hyde of cancer," Nature Reviews Cancer, vol. 6, no. 7, pp. 506-520, 2006.

[26] N. Moghal and P. W. Sternberg, "Multiple positive and negative regulators of signaling by the EGF-receptor," Current Opinion in Cell Biology, vol. 11, no. 2, pp. 190-196, 1999.

[27] O. Rho, L. M. Beltran, I. B. Gimenez-Conti, and J. DiGiovanni, "Altered expression of the epidermal growth factor receptor and transforming growth factor- $\alpha$ during multistage skin carcinogenesis in SENCAR mice," Molecular Carcinogenesis, vol. 11, no. 1, pp. 19-28, 1994.

[28] R. Samarakoon, C. E. Higgins, S. P. Higgins, and P. J. Higgins, "TGF- $\beta 1$-induced expression of the poor prognosis SERPINE1/PAI-1 gene requires EGFR signaling: a new target for anti-EGFR therapy," Journal of Oncology, vol. 2009, Article ID 342391, 6 pages, 2009.

[29] M. M. Murillo, G. del Castillo, A. Sánchez, M. Fernández, and I. Fabregat, "Involvement of EGF receptor and c-Src in the survival signals induced by TGF- $\beta 1$ in hepatocytes," Oncogene, vol. 24, no. 28, pp. 4580-4587, 2005.
[30] C.-K. Joo, H.-S. Kim, J.-Y. Park, Y. Seomun, M.-J. Son, and J.-T. Kim, "Ligand release-independent transactivation of epidermal growth factor receptor by transforming growth factor- $\beta$ involves multiple signaling pathways," Oncogene, vol. 27, no. 5, pp. 614-628, 2008.

[31] P. O-Charoenrat, P. Rhys-Evans, H. Modjtahedi, W. Court, G. Box, and S. Eccles, "Overexpression of epidermal growth factor receptor in human head and neck squamous carcinoma cell lines correlates with matrix metalloproteinase-9 expression and in vitro invasion," International Journal of Cancer, vol. 89, no. 2, pp. 307-317, 2000.

[32] P. O-charoenrat, P. H. Rhys-Evans, D. J. Archer, and S. A. Eccles, "C-erbB receptors in squamous cell carcinomas of the head and neck: clinical significance and correlation with matrix metalloproteinases and vascular endothelial growth factors," Oral Oncology, vol. 38, no. 1, pp. 73-80, 2002.

[33] J. Zavadil and E. P. Böttinger, "TGF- $\beta$ and epithelial-tomesenchymal transitions," Oncogene, vol. 24, no. 37, pp. 5764-5774, 2005.

[34] J. Zavadil, M. Bitzer, D. Liang, et al., "Genetic programs of epithelial cell plasticity directed by transforming growth factor- $\beta$," Proceedings of the National Academy of Sciences of the United States of America, vol. 98, no. 12, pp. 6686-6691, 2001.

[35] C. E. Wilkins-Port, Q. Ye, J. E. Mazurkiewicz, and P. J. Higgins, "TGF- $\beta 1$ + EGF-initiated invasive potential in transformed human keratinocytes is coupled to a plasmin/MMP10/MMP-1-dependent collagen remodeling axis: role for PAI-1," Cancer Research, vol. 69, no. 9, pp. 4081-4091, 2009.

[36] S. A. Mani, W. Guo, M.-J. Liao, et al., "The epithelialmesenchymal transition generates cells with properties of stem cells," Cell, vol. 133, no. 4, pp. 704-715, 2008.

[37] J. Yang and R. A. Weinberg, "Epithelial-mesenchymal transition: at the crossroads of development and tumor metastasis," Developmental Cell, vol. 14, no. 6, pp. 818-829, 2008.

[38] I. Nindl, C. Dang, T. Forschner, et al., "Identification of differentially expressed genes in cutaneous squamous cell carcinoma by microarray expression profiling," Molecular Cancer, vol. 5, pp. 1-17, 2006.

[39] C. Dang, M. Gottschling, K. Manning, et al., "Identification of dysregulated genes in cutaneous squamous cell carcinoma.," Oncology Reports, vol. 16, no. 3, pp. 513-519, 2006.

[40] S. Akiyoshi, M. Ishii, N. Nemoto, M. Kawabata, H. Aburatani, and K. Miyazono, "Targets of transcriptional regulation by transforming growth factor- $\beta$ : expression profile analysis using oligonucleotide arrays," Japanese Journal of Cancer Research, vol. 92, no. 3, pp. 257-268, 2001.

[41] G. Moreno-Bueno, E. Cubillo, D. Sarrió, et al., "Genetic profiling of epithelial cells expressing E-cadherin repressors reveals a distinct role for Snail, Slug, and E47 factors in epithelial- mesenchymal transition," Cancer Research, vol. 66, no. 19, pp. 9543-9556, 2006.

[42] P. A. Andreasen, L. Kjøller, L. Christensen, and M. J. Duffy, "The urokinase-type plasminogen activator system in cancer metastasis: a review," International Journal of Cancer, vol. 72, no. 1, pp. 1-22, 1997.

[43] B. Hundsdorfer, H. F. Zeilhofer, K. P. Bock, P. Dettmar, M. Schmitt, and H. H. Horch, "The prognostic importance of urinase type plasminogen activators (uPA) and plasminogen activator inhibitors (PAI-1) in the primary resection of oral squamous cell carcinoma," Mund-, Kieferund Gesichtschirurgie, vol. 8, no. 3, pp. 173-179, 2004. 
[44] K. Annecke, M. Schmitt, U. Euler, et al., "uPA and PAI-1 in breast cancer: review of their clinical utility and current validation in the prospective NNBC-3 trial," Advances in Clinical Chemistry, vol. 45, pp. 31-45, 2008.

[45] N. Harbeck, M. Schmitt, S. Paepke, H. Allgayer, and R. E. Kates, "Tumor-associated proteolytic factors uPA and PAI-1: critical appraisal of their clinical relevance in breast cancer and their integration into decision-support algorithms," Critical Reviews in Clinical Laboratory Sciences, vol. 44, no. 2, pp. 179-201, 2007.

[46] E. Vairaktaris, C. Yapijakis, Z. Serefoglou, et al., "Plasminogen activator inhibitor-1 polymorphism is associated with increased risk for oral cancer," Oral Oncology, vol. 42, no. 9, pp. 888-892, 2006.

[47] K. Bajou, V. Masson, R. D. Gerard, et al., "The plasminogen activator inhibitor PAI-1 controls in vivo tumor vascularization by interaction with proteases, not vitronectin: implications for antiangiogenic strategies," Journal of Cell Biology, vol. 152, no. 4, pp. 777-784, 2001.

[48] K. Bajou, A. Noel, R. D. Gerard, et al., "Absence of host plasminogen activator inhibitor 1 prevents cancer invasion and vascularization," Nature Medicine, vol. 4, no. 8, pp. 923 928, 1998.

[49] G. E. Davis, K. A. Pintar Allen, R. Salazar, and S. A. Maxwell, "Matrix metalloproteinase- 1 and -9 activation by plasmin regulates a novel endothelial cell-mediated mechanism of collagen gel contraction and capillary tube regression in three-dimensional collagen matrices," Journal of Cell Science, vol. 114, no. 5, pp. 917-930, 2001.

[50] S. P. Higgins, R. Samarakoon, C. E. Higgins, J. Freytag, C. Wilkins-Port, and P. J. Higgins, "TGF- $\beta 1$-induced expression of the anti-apoptotic PAI-1 protein requires EGFR signaling," Cell Communication Insights, vol. 2, pp. 1-11, 2009.

[51] C. Maillard, M. Jost, M. U. Rømer, et al., "Host plasminogen activator inhibitor-1 promotes human skin carcinoma progression in a stage-dependent manner," Neoplasia, vol. 7, no. 1, pp. 57-66, 2005.

[52] E. Bacharach, A. Itin, and E. Keshet, "Apposition-dependent induction of plasminogen activator inhibitor type 1 expression: a mechanism for balancing pericellular proteolysis during angiogenesis," Blood, vol. 92, no. 3, pp. 939-945, 1998.

[53] K. M. Providence, S. P. Higgins, A. Mullen, A. Battista, C. E. Higgins, and P. J. Higgins, "SERPINE1 (PAI-1) is deposited into keratinocyte migration "trails" and required for optimal monolayer wound repair," Archives of Dermatological Research, vol. 300, no. 6, pp. 303-310, 2008.

[54] C. E. Wilkins-Port, C. E. Higgins, J. Freytag, S. P. Higgins, J. A. Carlson, and P. J. Higgins, "PAI-1 is a critical upstream regulator of the TGF- $\beta 1 /$ EGF-induced invasive phenotype in mutant p53 human cutaneous squamous cell carcinoma," Journal of Biomedicine and Biotechnology, vol. 2007, pp. 1-8, 2007.

[55] M. Illemann, U. Hansen, H. J. Nielsen, et al., "Leading-edge myofibroblasts in human colon cancer express plasminogen activator inhibitor-1," American Journal of Clinical Pathology, vol. 122, no. 2, pp. 256-265, 2004.

[56] B. V. Offersen, B. S. Nielsen, G. Høyer-Hansen, et al., "The myofibroblast is the predominant plasminogen activator inhibitor-1-expressing cell type in human breast carcinomas," American Journal of Pathology, vol. 163, no. 5, pp. 18871899, 2003.

[57] F. Maquerlot, S. Galiacy, M. Malo, et al., "Dual role for plasminogen activator inhibitor type 1 as soluble and as matricellular regulator of epithelial alveolar cell wound healing," American Journal of Pathology, vol. 169, no. 5, pp. 1624-1632, 2006.

[58] S. Parrinello, J.-P. Coppe, A. Krtolica, and J. Campisi, "Stromal-epithelial interactions in aging and cancer: senescent fibroblasts alter epithelial cell differentiation," Journal of Cell Science, vol. 118, no. 3, pp. 485-496, 2005.

[59] M. Giannopoulou, S. C. Iszkula, C. Dai, et al., "Distinctive role of Stat 3 and Erk-1/2 activation in mediating interferon- $\gamma$ inhibition of TGF- $\beta 1$ action," American Journal of Physiology, vol. 290, no. 5, pp. F1234-F1240, 2006.

[60] J. Freytag, C. E. Wilkins-Port, C. E. Higgins, S. P. Higgins, R. Samarakoon, and P. J. Higgins, "PAI-1 mediates the TGF$\beta 1+$ EGF-induced "scatter"-response in transformed human keratinocytes," Journal of Investigative Dermatology. In press.

[61] M. Davies, M. Robinson, E. Smith, S. Huntley, S. Prime, and I. Paterson, "Induction of an epithelial to mesenchymal transition in human immortal and malignant keratinocytes by TGF- $\beta 1$ involves MAPK, Smad and AP-1 signalling pathways," Journal of Cellular Biochemistry, vol. 95, no. 5, pp. 918-931, 2005.

[62] D. Chin, G. M. Boyle, P. G. Parsons, and W. B. Coman, "What is transforming growth factor-beta (TGF- $\beta$ )?" British Journal of Plastic Surgery, vol. 57, no. 3, pp. 215-221, 2004.

[63] C. H. Streuli, C. Schmidhauser, M. Kobrin, M. J. Bissell, and R. Derynck, "Extracellular matrix regulates expression of the TGF- $\beta 1$ gene," Journal of Cell Biology, vol. 120, no. 1, pp. 253260, 1993.

[64] T. M. Vollberg Sr., M. D. George, and A. M. Jetten, "Induction of extracellular matrix gene expression in normal human keratinocytes by transforming growth factor $\beta$ is altered by cellular differentiation," Experimental Cell Research, vol. 193, no. 1, pp. 93-100, 1991.

[65] N. E. Wikner, J. T. Elder, K. A. Persichitte, P. Mink, and R. A. F. Clark, "Transforming growth factor- $\beta$ modulates plasminogen activator activity and plasminogen activator inhibitor type-1 expression in human keratinocytes in vitro," Journal of Investigative Dermatology, vol. 95, no. 5, pp. 607613, 1990.

[66] K. Ahokas, J. Lohi, S. A. Illman, et al., "Matrix metalloproteinase-21 is expressed epithelially during development and in cancer and is up-regulated by transforming growth factor- $\beta 1$ in keratinocytes," Laboratory Investigation, vol. 83, no. 12, pp. 1887-1899, 2003.

[67] N. Johansson, J. Westermarck, S. Leppä, et al., "Collagenase 3 (matrix metalloproteinase 13) gene expression by $\mathrm{HaCaT}$ keratinocytes is enhanced by tumor necrosis factor $\alpha$ and transforming growth factor $\beta 1$," Cell Growth and Differentiation, vol. 8, no. 2, pp. 243-250, 1997.

[68] E. S. Kim, M. S. Kim, and A. Moon, "TGF-beta-induced upregulation of MMP-2 and MMP-9 depends on p38 MAPK, but not ERK signaling in MCF10A human breast epithelial cells.", International Journal of Oncology, vol. 25, no. 5, pp. 1375-1382, 2004.

[69] E.-S. Kim, M.-S. Kim, and A. Moon, "Transforming growth factor (TGF) $\beta$ in conjunction with H-ras activation promotes malignant progression of MCF10A breast epithelial cells," Cytokine, vol. 29, no. 2, pp. 84-91, 2005.

[70] H.-S. Kim, T. Shang, Z. Chen, S. C. Pflugfelder, and D.-Q. $\mathrm{Li}$, "TGF- $\beta 1$ stimulates production of gelatinase (MMP-9), collagenases (MMP-1, -13) and stromelysins (MMP-3, -10, -11) by human corneal epithelial cells," Experimental Eye Research, vol. 79, no. 2, pp. 263-274, 2004.

[71] H. G. Munshi, Y. I. Wu, S. Mukhopadhyay, et al., "Differential regulation of membrane type 1-matrix metalloproteinase 
activity by ERK 1/2- and p38 MAPK-modulated tissue inhibitor of metalloproteinases 2 expression controls transforming growth factor- $\beta 1$-induced pericellular collagenolysis," Journal of Biological Chemistry, vol. 279, no. 37, pp. 39042-39050, 2004.

[72] L. J. Windsor, H. Grenett, B. Birkedal-Hansen, M. K. Bodden, J. A. Engler, and H. Birkedal-Hansen, "Cell type-specific regulation of SL-1 and SL-2 genes. Induction of the SL2 gene but not the SL-1 gene by human keratinocytes in response to cytokines and phorbolesters," Journal of Biological Chemistry, vol. 268, no. 23, pp. 17341-17347, 1993.

[73] M. Madlener, C. Mauch, W. Conca, M. Brauchle, W. C. Parks, and S. Werner, "Regulation of the expression of stromelysin2 by growth factors in keratinocytes: implications for normal and impaired wound healing," Biochemical Journal, vol. 320, no. 2, pp. 659-664, 1996.

[74] S. Chakraborti, M. Mandal, S. Das, A. Mandal, and T. Chakraborti, "Regulation of matrix metalloproteinases. An overview," Molecular and Cellular Biochemistry, vol. 253, no. 1-2, pp. 269-285, 2003.

[75] P. O-charoenrat, P. H. Rhys-Evans, and S. A. Eccles, "Expression of matrix metalloproteinases and their inhibitors correlates with invasion and metastasis in squamous cell carcinoma of the head and neck," Archives of Otolaryngology, vol. 127, no. 7, pp. 813-820, 2001.

[76] U. Impola, V. J. Uitto, J. Hietanen, et al., "Differential expression of matrilysin-I (MMP-7), $92 \mathrm{kD}$ gelatinase (MMP9 ), and metalloelastase (MMP-12) in oral verrucous and squamous cell cancer," Journal of Pathology, vol. 202, no. 1, pp. 14-22, 2004.

[77] E. Kerkelä, R. Ala-aho, L. Jeskanen, et al., "Differential patterns of stromelysin-2 (MMP-10) and MT1-MMP (MMP14) expression in epithelial skin cancers," British Journal of Cancer, vol. 84, no. 5, pp. 659-669, 2001.

[78] R. Mathew, R. Khanna, R. Kumar, M. Mathur, N. K. Shukla, and R. Ralhan, "Stromelysin-2 overexpression in human esophageal squamous cell carcinoma: potential clinical implications," Cancer Detection and Prevention, vol. 26, no. 3, pp. 222-228, 2002.

[79] M. Krampert, W. Bloch, T. Sasaki, et al., "Activities of the matrix metalloproteinase stromelysin-2 (MMP-10) in matrix degradation and keratinocyte organization in wounded skin," Molecular Biology of the Cell, vol. 15, no. 12, pp. 52425254, 2004.

[80] S. Uttamsingh, X. Bao, K. T. Nguyen, et al., "Synergistic effect between EGF and TGF- $\beta 1$ in inducing oncogenic properties of intestinal epithelial cells," Oncogene, vol. 27, no. 18, pp. 2626-2634, 2008.

[81] F.-C. Hsieh, G. Cheng, and J. Lin, "Evaluation of potential Stat3-regulated genes in human breast cancer," Biochemical and Biophysical Research Communications, vol. 335, no. 2, pp. 292-299, 2005.

[82] M. Itoh, T. Murata, T. Suzuki, et al., "Requirement of STAT3 activation for maximal collagenase-1 (MMP-1) induction by epidermal growth factor and malignant characteristics in T24 bladder cancer cells," Oncogene, vol. 25, no. 8, pp. 1195-1204, 2006.

[83] N. Sumita, T. Bito, K. Nakajima, and C. Nishigori, "Stat3 activation is required for cell proliferation and tumorigenesis but not for cell viability in cutaneous squamous cell carcinoma cell lines," Experimental Dermatology, vol. 15, no. 4, pp. 291299, 2006.

[84] C. Suiqing, Z. Min, and C. Lirong, "Overexpression of phosphorylated-STAT3 correlated with the invasion and metastasis of cutaneous squamous cell carcinoma," Journal of Dermatology, vol. 32, no. 5, pp. 354-360, 2005.

[85] S. M. Kutz, C. E. Higgins, R. Samarakoon, et al., "TGF$\beta 1$-induced PAI-1 expression is E box/USF-dependent and requires EGFR signaling," Experimental Cell Research, vol. 312, no. 7, pp. 1093-1105, 2006.

[86] R. Samarakoon, C. E. Higgins, S. P. Higgins, S. M. Kutz, and P. J. Higgins, "Plasminogen activator inhibitor type-1 gene expression and induced migration in TGF- $\beta 1$-stimulated smooth muscle cells is $p p 60^{\mathrm{c}-s r c} / \mathrm{MEK}$-dependent," Journal of Cellular Physiology, vol. 204, no. 1, pp. 236-246, 2005.

[87] P. P.-C. Hu, X. Shen, D. Huang, Y. Liu, C. Counter, and X.F. Wang, "The MEK pathway is required for stimulation of p21(WAF1/CIP1) by transforming growth factor- $\beta$," Journal of Biological Chemistry, vol. 274, no. 50, pp. 35381-35387, 1999.

[88] M. Sato, K. Kawai-Kowase, H. Sato, et al., "c-Src and hydrogen peroxide mediate transforming growth factor- $\beta 1$ induced smooth muscle cell-gene expression in 10T1/2 cells," Arteriosclerosis, Thrombosis, and Vascular Biology, vol. 25, no. 2, pp. 341-347, 2005.

[89] M. Oft, J. Peli, C. Rudaz, H. Schwarz, H. Beug, and E. Reichmann, "TGF- $\beta 1$ and Ha-Ras collaborate in modulating the phenotypic plasticity and invasiveness of epithelial tumor cells," Genes and Development, vol. 10, no. 19, pp. 2462-2477, 1996.

[90] M. Oft, R. J. Akhurst, and A. Balmain, "Metastasis is driven by sequential elevation of H-ras and Smad2 levels," Nature Cell Biology, vol. 4, no. 7, pp. 487-494, 2002.

[91] J. S. Biscardi, M. C. Maa, D. A. Tice, M. E. Cox, T. H. Leu, and S. J. Parsons, "c-Src-mediated phosphorylation of the epidermal growth factor receptor on tyr 845 and tyr 1101 is associated with modulation of receptor function," Journal of Biological Chemistry, vol. 274, pp. 8335-8343, 1999.

[92] L. M. Beaulieu, B. R. Whitley, T. F. Wiesner, et al., "Breast cancer and metabolic syndrome linked through the plasminogen activator inhibitor-1 cycle," BioEssays, vol. 29, no. 10, pp. 1029-1038, 2007.

[93] L. Moro, L. Dolce, S. Cabodi, et al., "Integrin-induced epidermal growth factor (EGF) receptor activation requires c-Src and p130Cas and leads to phosphorylation of specific EGF receptor tyrosines," Journal of Biological Chemistry, vol. 277, no. 11, pp. 9405-9414, 2002.

[94] C. K. Miranti and J. S. Brugge, "Sensing the environment: a historical perspective on integrin signal transduction," Nature Cell Biology, vol. 4, no. 4, pp. E83-E90, 2002.

[95] J.-T. Kim and C.-K. Joo, "Involvement of cell-cell interactions in the rapid stimulation of Cas tyrosine phosphorylation and Src kinase activity by transforming growth factor- $\beta 1$," Journal of Biological Chemistry, vol. 277, no. 35, pp. 31938-31948, 2002.

[96] F. W. Khwaja, P. Svoboda, M. Reed, J. Pohl, B. Pyrzynska, and E. G. Van Meir, "Proteomic identification of the wt-p53regulated tumor cell secretome," Oncogene, vol. 25, no. 58, pp. 7650-7661, 2006.

[97] S. Piccolo, "p53 regulation orchestrates the TGF- $\beta$ response," Cell, vol. 133, no. 5, pp. 767-769, 2008.

[98] M. Cordenonsi, S. Dupont, S. Maretto, A. Insinga, C. Imbriano, and S. Piccolo, "Links between tumor suppressors: p53 is required for TGF- $\beta$ gene responses by cooperating with Smads," Cell, vol. 113, no. 3, pp. 301-314, 2003. 
[99] M. Cordenonsi, M. Montagner, M. Adorno, et al., "Integration of TGF- $\beta$ and Ras/MAPK signaling through p53 phosphorylation," Science, vol. 315, no. 5813, pp. 840-843, 2007.

[100] S. Dupont, L. Zacchigna, M. Adorno, et al., "Convergence of p53 and TGF $\beta$ signaling networks," Cancer Letters, vol. 213, no. 2, pp. 129-138, 2004.

[101] C. Kunz, S. Pebler, J. Otte, and D. von der Ahe, "Differential regulation of plasminogen activator and inhibitor gene transcription by the tumor suppressor p53," Nucleic Acids Research, vol. 23, no. 18, pp. 3710-3717, 1995.

[102] T. Riley, E. Sontag, P. Chen, and A. Levine, "Transcriptional control of human p53-regulated genes," Nature Reviews Molecular Cell Biology, vol. 9, no. 5, pp. 402-412, 2008.

[103] S. Shetty, P. Shetty, S. Idell, T. Velusamy, Y. P. Bhandary, and R. S. Shetty, "Regulation of plasminogen activator inhibitor1 expression by tumor suppressor protein p53," Journal of Biological Chemistry, vol. 283, no. 28, pp. 19570-19580, 2008.

[104] R. R. Allen, L. Qi, and P. J. Higgins, "Upstream stimulatory factor regulates E box-dependent PAI-1 transcription in human epidermal keratinocytes," Journal of Cellular Physiology, vol. 203, no. 1, pp. 156-165, 2005.

[105] D. E. Fisher, L. A. Parent, and P. A. Sharp, "Myc/Max and other helix-loop-helix/leucine zipper proteins bend DNA toward the minor groove," Proceedings of the National Academy of Sciences of the United States of America, vol. 89, no. 24, pp. 11779-11783, 1992.

[106] N. Scheinfeld and V. DeLeo, "Etiological factors in skin cancers: environmental and biological," in Cancer of the Skin, D. S. Rigel, R. J. Friedman, L. M. Dzubow, D. S. Reintgen, J.-C. Bystryn, and R. Marks, Eds., pp. 61-70, Elsevier, Philadelphia, Pa, USA, 2005.

[107] R. M. Kortlever, P. J. Higgins, and R. Bernards, "Plasminogen activator inhibitor-1 is a critical downstream target of p53 in the induction of replicative senescence," Nature Cell Biology, vol. 8, no. 8, pp. 878-884, 2006.

[108] R. D. Balsara, F. J. Castellino, and V. A. Ploplis, "A novel function of plasminogen activator inhibitor-1 in modulation of the AKT pathway in wild-type and plasminogen activator inhibitor-1-deficient endothelial cells," Journal of Biological Chemistry, vol. 281, no. 32, pp. 22527-22536, 2006.

[109] R. M. Kortlever, J. H. Nijwening, and R. Bernards, "Transforming growth factor- $\beta$ requires its target plasminogen activator inhibitor-1 for cytostatic activity," Journal of Biological Chemistry, vol. 283, no. 36, pp. 24308-24313, 2008. 


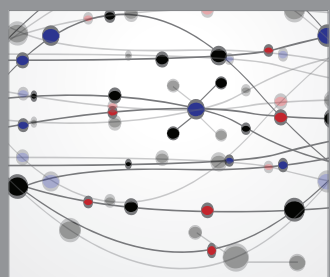

The Scientific World Journal
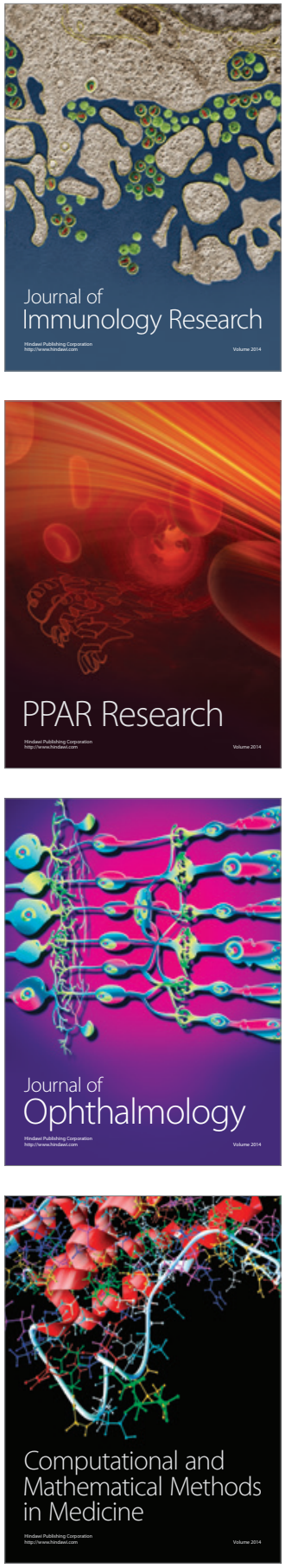

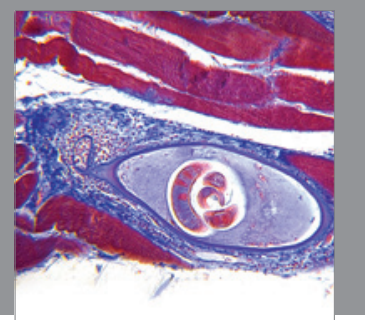

Gastroenterology

Research and Practice
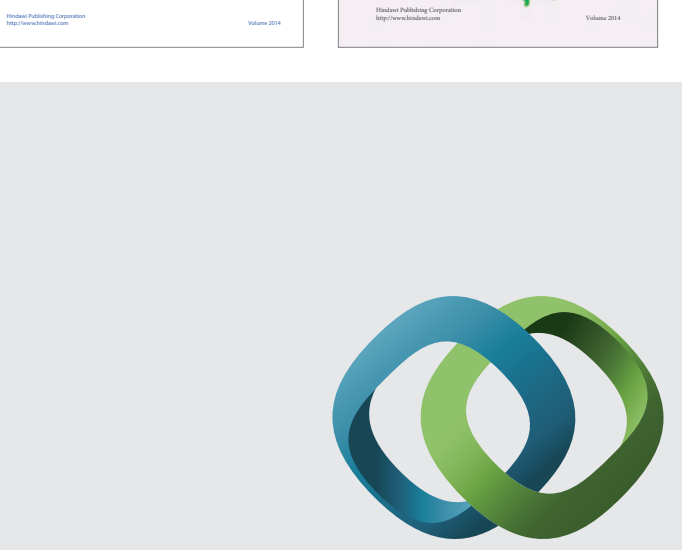

\section{Hindawi}

Submit your manuscripts at

http://www.hindawi.com
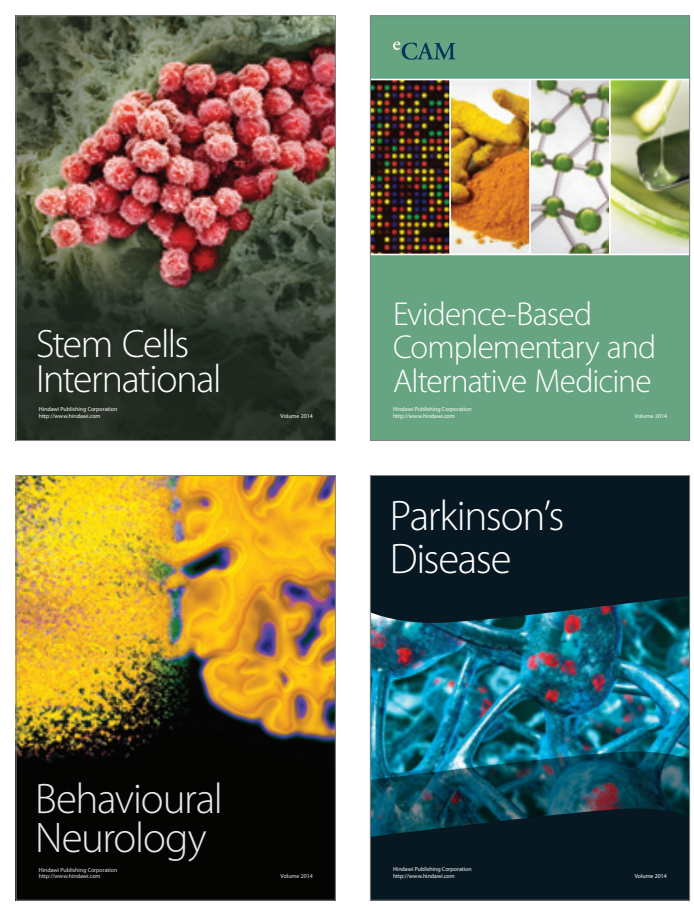

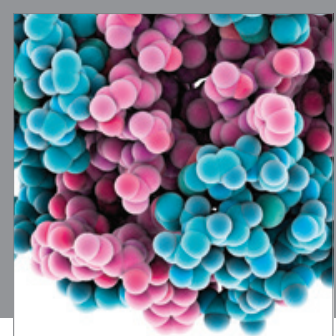

Journal of
Diabetes Research

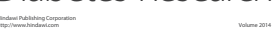

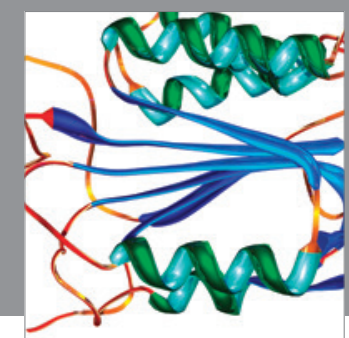

Disease Markers
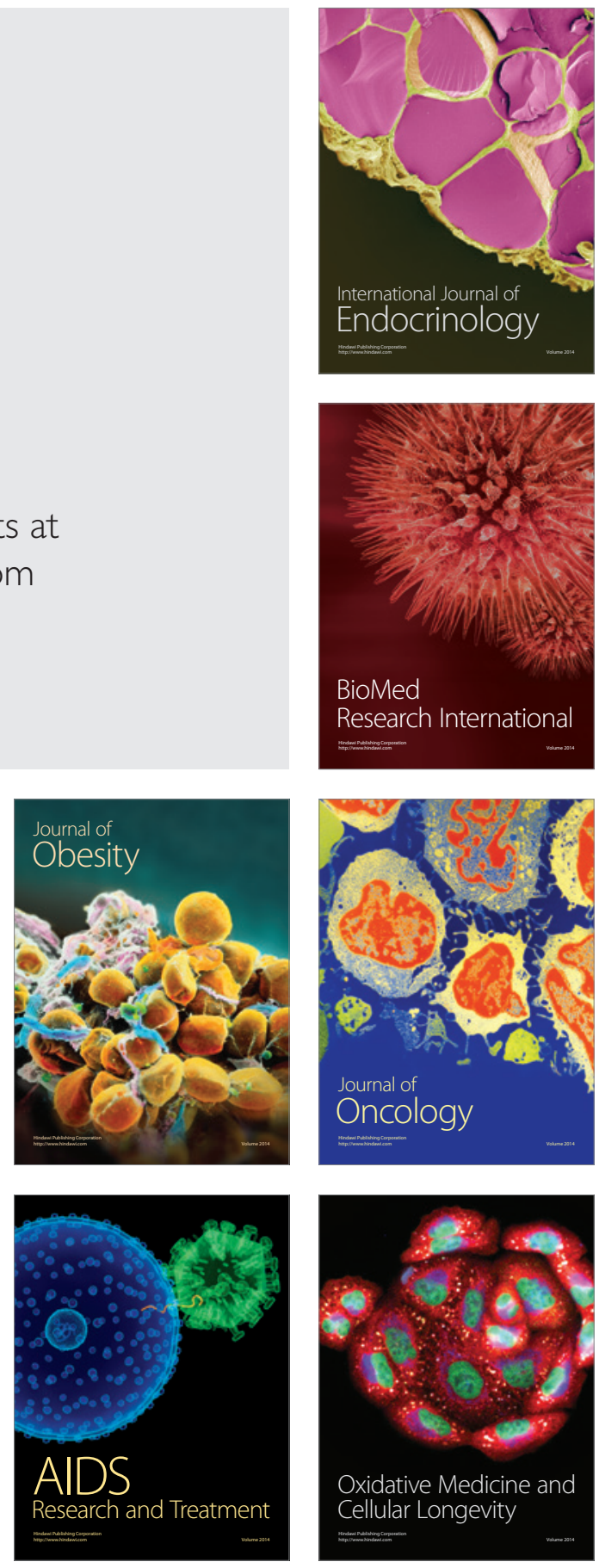